\title{
Visualisasi Berbasis Web Indeks Aksesibilitas Fasilitas Kesehatan di Kota Bogor
}

\author{
Web-based Visualization for Health Facilities Accessibility Index in Bogor City \\ Rina Trisminingsih $^{1^{*}}$ \& Citra Hasana Sagala ${ }^{1}$ \\ ${ }^{1}$ Departemen Ilmu Komputer, Institut Pertanian Bogor, Jl. Meranti Wing 22 Level 5 \\ Kampus IPB Dramaga, Bogor 16680; "Penulis korespondensi, e-mail: rina.ilkomipb@gmail.com
}

(Diterima: 14 April 2017; Disetujui: 24 Juli 2017)

\begin{abstract}
Bogor City has health facilities about 19 hospitals, 24 puskesmas, and 94 clinics. Accessing health facilities need some consideration such as distance or accessibility to the health facilities. The objective of the research is to determine and present accessibility index to the health facilities. Accessibility/Remoteness Index of Australia (ARIA) method is chosen to calculate and classify the accessibility index of health facilities in Bogor City. There are several steps to do such as making basic map, calculating and classifiying accessibility index, then developing visualization module. Web-based visualisation modul is developed by OpenGeo suite technology. Accessibility index calculation is held in an area (grid and kelurahan) to the health facilities (hospitals, puskesmas, clinics). The results obtained $2.27 \%$ grid and $8.46 \%$ villages in Bogor City has low level access to all health facilities. From the visualization showed that Mulyaharja village is an area which have the lowest accessibility index in Bogor City.
\end{abstract}

Keywords: accessibility index, ARIA, health facilities, visualization module

\begin{abstract}
ABSTRAK
Kota Bogor memiliki fasilitas kesehatan berupa rumah sakit, puskesmas, dan klinik yang tersebar pada beberapa wilayah. Untuk dapat mengakses fasilitas kesehatan tersebut dibutuhkan beberapa pertimbangan, salah satunya adalah jarak/akses menuju suatu fasilitas kesehatan. Penelitian ini bertujuan menentukan tingkat akses atau indeks aksesibilitas menuju fasilitas kesehatan dan memvisualisasikannya. Metode Accessibility Remoteness Index of Australia (ARIA) dipilih untuk menghitung dan mengklasifikasikan indeks aksesibilitas menuju fasilitas kesehatan di Kota Bogor. Ada beberapa tahap yang perlu dilakukan seperti membuat peta dasar, menghitung serta mengklasifikasi indeks aksesibilitas. Modul visualisasi dikembangkan berbasis web dengan teknologi OpenGeo Suite. Perhitungan indeks aksesibilitas dilakukan pada suatu wilayah (grid dan kelurahan) terhadap fasilitas kesehatan (rumah sakit, puskesmas, dan klinik). Dari hasil perhitungan yang diperoleh bahwa sebanyak $2.27 \%$ wilayah grid dan $8.46 \%$ wilayah kelurahan di wilayah Kota Bogor memiliki tingkat akses rendah terhadap seluruh fasilitas kesehatan. Dari hasil visualisasi terlihat bahwa Kelurahan Mulyaharja merupakan wilayah yang memiliki indeks aksesibilitas rendah.

Kata kunci: ARIA, fasilitas kesehatan,indeks aksesibilitas, modul visualisasi
\end{abstract}




\section{PENDAHULUAN}

Kesehatan adalah hal yang tidak dapat dipisahkan dalam kehidupan manusia. Kesehatan merupakan komponen utama setelah pendapatan dan pendidikan dalam Indeks Pembangunan Manusia (IPM). Pemerintah baik pusat maupun daerah wajib menjamin hak rakyat untuk memperoleh kesehatan sesuai Undang-Undang Nomor 36 Tahun 2009 tentang Kesehatan. Pemerintah Kota Bogor sebagai salah satu daerah yang berkembang juga memprioritaskan kesehatan sebagai program kerjanya. Hal-hal yang diprioritaskan Pemerintah, khususnya Kota Bogor, adalah membangun fasilitas kesehatan yang terjangkau oleh masyarakat umum secara luas. Hal ini dilakukan karena salah satu faktor yang mempengaruhi kualitas pelayanan kesehatan adalah tingkat akses ke fasilitas kesehatan (Haryanto 2007).

Beberapa penelitian telah dilakukan untuk menentukan tingkat akses terhadap fasilitas umum, termasuk fasilitas kesehatan. Salah satunya metode perhitungan indeks aksesibilitas yaitu Accessibility Remoteness Index of Australia (ARIA), metode yang dikembangkan oleh Departemen Kesehatan Universitas Adelaide untuk menentukan indeks aksesibilitas rumah sakit terhadap daerah terpencil di Australia. Metode ini mudah diterapkan karena tidak memperhatikan faktor sosial ekonomi suatu wilayah (GISCA 2001). Metode ini sederhana dan dapat digunakan untuk menentukan indeks aksesibilitas menuju fasilitas kesehatan suatu daerah tidak hanya di Australia. Metode ini dapat diterapkan dengan studi kasus wilayah yang berbeda dengan membedakan ukuran indeksnya. ARIA juga merupakan salah satu penelitian Institut Kesehatan dan Kesejahteraan Canbera Australia untuk menentukan tingkat akses daerah terpencil menuju fasilitas kesehatan (AIHW 2004). Metode ini juga telah diterapkan juga oleh Hadi et al. (2013) untuk menghitung aksesibilitas menuju fasilitas kesehatan di Kota Bandung. Metode lain untuk menentukan tingkat aksesibilitas pelayanan kesehatan pada suatu wilayah yaitu dengan pendekatan Geographics Information System (GIS). Ahmad (2012) memanfaatkan GIS untuk menentukan aksesibilitas terhadap layanan kesehatan di wilayah Melbourne, Australia.

Penelitian ini bertujuan menentukan indeks aksesibilitas fasilitas kesehatan di Kota Bogor menggunakan metode ARIA, mengklasifikasikan indeks aksesibilitas yang mengacu pada metode penelitian yang dilakukan oleh Hadi et al. (2013), serta mengembangkan modul visualisasi dalam bentuk peta berbasis web untuk hasil klasifikasi indeks aksesibilitas dengan teknologi Geoserver. Menurut Sarup dan Shukla (2012) GeoServer merupakan perangkat open source yang dapat menggantikan software komersil untuk pembuatan peta berbasis web skala kecil maupun menengah. Modul visualisasi pada Geoserver dapat menampilkan navigasi peta dasar seperti fitur memperbesar dan memperkecil peta, legenda peta, skala peta dan fungsi lainnya. Modul visualisasi dibutuhkan untuk mempermudah analisis hasil klasifikasi indeks aksesibilitas fasilitas kesehatan. Hasil dari penelitian ini diharapkan menjadi pertimbangan bagi pemerintah dalam hal peningkatan fasilitas kesehatan.

\section{METODE}

Penelitian ini dilaksanakan dengan menggunakan beberapa tahapan yaitu, tahap praproses yang dilakukan dengan pengumpulan data dan pembuatan peta dasar Kota Bogor, tahap perhitungan indeks aksesibilitas, klasifikasi dan analisis indeks, kemudian dilakukan pembuatan modul visualisasi hasil klasifikasi (Gambar 1). 


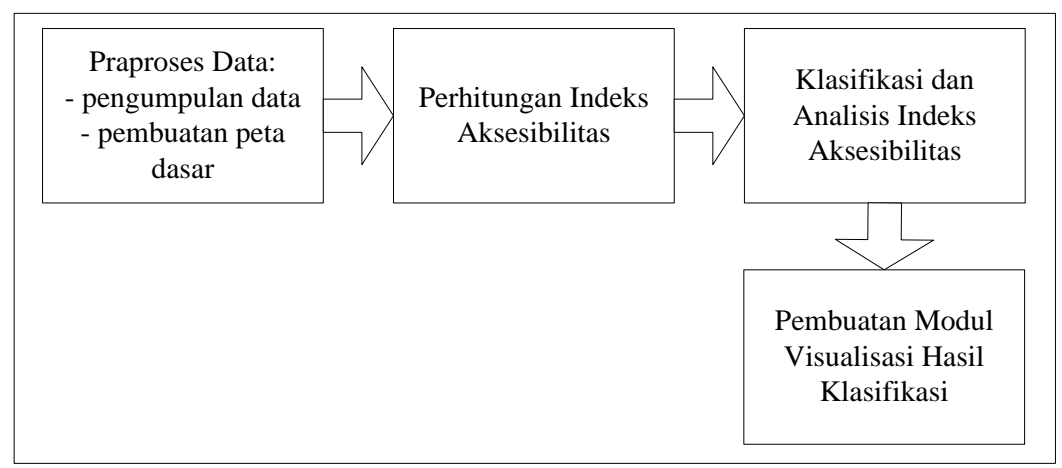

Gambar 1. Tahapan penelitian

Data fasilitas kesehatan dikumpulkan dari berbagai sumber untuk kemudian dikelompokkan menjadi tiga kategori yaitu: rumah sakit, puskesmas, dan klinik. Pembuatan peta dasar dilakukan dengan melakukan digitasi batas wilayah Kota Bogor, overlay lokasi fasilitas kesehatan dan jalan, serta melakukan partisi wilayah dengan pendekatan grid dan kelurahan. Partisi dengan dua pendekatan ini dilakukan untuk membandingkan hasil klasifikasi indeks aksesibilitas dengan memperhatikan perbedaan luas wilayah setiap kelas indeks aksesibilitas.

Perhitungan indeks aksesibilitas dilakukan menggunakan metode Accessibility or Remoteness Indeks of Australia (ARIA). ARIA dirancang agar tidak ambigu secara geografi dalam mengidentifikasi wilayah yang terakses. Faktor sosial ekonomi, faktor perkotaan (urban) atau pedesaan (rural), serta populasi penduduk tidak diperhitungkan dalam pengukuran indeks ini. Metode ini membagi wilayah Kota Bogor menjadi grid yang memiliki luas $1 \mathrm{~km}$ dan wilayah kelurahan. Seperti pada Persamaan 1, dengan $A_{i j}$ merupakan nilai indeks aksesibilitas, $d_{i j}$ merupakan jarak terdekat daerah $i$ menuju fasilitas kesehatan $j$ dan $d_{j}$ merupakan rata-rata seluruh jarak terdekat menuju fasilitas kesehatan $j$.

$$
A_{i j}=\frac{d_{i j}}{d_{j}}
$$

Penelitian ini menggunakan metode klasifikasi indeks aksesibilitas seperti yang dilakukan Hadi et al. (2013) dengan membagi kelas dalam interval yang sama serta menentukan indeks minimum dan maksimum terlebih dahulu. Menurut data statistik Kota Bogor yang diterbitkan oleh BPS (2016) mengenai luas wilayah dan jumlah penduduk menurut kecamatan Kota Bogor terdapat keterangan mengenai kepadatan penduduk setiap kecamatan yang ada di Kota Bogor. Berdasarkan definisi setiap kelas pada ARIA menurut GISCA (2001) jika dibandingkan dengan kepadatan penduduk di Kota Bogor, diasumsikan bahwa tidak ada daerah yang memiliki tingkat akses Sangat Rendah terhadap fasilitas kesehatan, sehingga kelas yang digunakan hanya 4 kelas, yaitu sangat tinggi, tinggi, sedang, dan rendah.

Rentang indeks dapat dihitung menggunakan Persamaan 2. Dengan $a_{\max }$ merupakan indeks aksesibilitas terbesar menuju fasilitas kesehatan $j, \quad a_{\min }$ adalah indeks aksesibilitas terkecil menuju fasilitas kesehatan $j$, dan $x$ adalah jangkauan tingkatan aksesibilitas.

$$
x=\frac{a_{\max }-a_{\min }}{\text { Jumlah Kelas }}
$$

Hasil klasifikasi indeks askesibilitas kemudian ditampilkan dalam web sehingga dapat mempermudah dalam menganalisis hasil klasifikasi. Visualisasi berbasis web yang dibuat menggunakan OpenGeo Suite, teknologi yang mendukung dalam menampilkan peta berbasis web.

\section{HASIL DAN PEMBAHASAN}

\section{Praproses Data}

Ada dua langkah yang dilakukan pada praproses data, yaitu pengumpulan data dan 
pembuatan peta dasar Kota Bogor. Pengumpulan data dilakukan menggunakan dua situs yaitu situs Kementrian Kesehatan RI dan BPJS Kesehatan. Dari hasil pencarian diperoleh data bahwa Kota Bogor memiliki sebanyak 62 fasilitas kesehatan yaitu 16 rumah sakit, 24 puskesmas, dan 22 klinik. Data peta dasar diperoleh dari situs Permukiman, Percepatan Pembangunan, dan Sanitasi (PPSP) (2010) yang menampilkan peta batas wilayah Kota Bogor dengan partisi wilayah berdasarkan kelurahan. Peta jalan diperoleh dari data Open Street Maps.

Pembuatan peta dasar Kota Bogor dilakukan menggunakan tiga langkah. Pertama, digitasi peta batas wilayah administrasi Kota Bogor yang mengacu pada situs PPSP (2010). Kedua, partisi wilayah menggunakan dua pendekatan, yaitu partisi wilayah grid dan partisi wilayah kelurahan, kemudian dilakukan digitasi sentroid untuk setiap wilayah. Partisi wilayah grid sebesar $1000 \mathrm{~m}$ atau $1 \mathrm{~km}$ merupakan ketentuan dari ARIA. Ketiga, overlay fasilitas kesehatan dan jalan dengan menggunakan bantuan peta digital seperti OpenStreet Maps atau Google Maps.

\section{Hasil Perhitungan Indeks Aksesibilitas}

Perhitungan jarak setiap sentroid ke setiap fasilitas kesehatan diperoleh dari jarak dari setiap sentroid ke sekelompok fasilitas. Hal ini diterapkan untuk setiap kategori fasilitas kesehatan dengan menentukan jarak minimum setiap sentroid serta menghitung rata-rata jarak minimum menuju fasilitas kesehatan. Klasifikasi dilakukan dengan menentukan rentang indeks aksesibilitas untuk setiap kelas, kemudian mengklasifikasi indeks yang sudah ditentukan. Persamaan 2 digunakan untuk menentukan interval setiap rentang indeks. Perhitungan untuk wilayah grid dan kelurahan dibedakan sehingga diperoleh rentang setiap kelas seperti pada Tabel 1 dan Tabel 2.

Perhitungan indeks maksimum menuju fasilitas kesehatan dari sentroid setiap grid, kelompok fasilitas kesehatan rumah sakit diperoleh hasil perhitungan nilai indeks maksimum 2.5315. Kelompok puskesmas diperoleh hasil perhitungan nilai maksimum 3.1513. Kelompok klinik diperoleh hasil perhitungan nilai maksimum 2.8066. Keseluruhan fasilitas kesehatan diperoleh hasil perhitungan nilai maksimum 3.5696. Berdasarkan nilai indeks maksimum yang diperoleh, kelompok rumah sakit memiliki indeks maksimum paling kecil daripada fasilitas kesehatan lainnya.

Tabel 1. Kelas indeks aksesibilitas grid menuju fasilitas kesehatan

\begin{tabular}{cll}
\hline $\begin{array}{c}\text { Fasilitas } \\
\text { Kesehatan }\end{array}$ & $\begin{array}{c}\text { Kelas } \\
\text { Aksesibilitas }\end{array}$ & Rentang Indeks \\
\hline Rumah & Sangat & $0.0567-0.6754$ \\
Sakit & Tinggi & \\
& Tinggi & $0.6754-1.2941$ \\
& Sedang & $1.2941-1.9128$ \\
& Rendah & $1.9128-2.5315$ \\
Puskesmas & Sangat & $0.0318-0.8117$ \\
& Tinggi & \\
& Tinggi & $0.8117-1.5915$ \\
Klinik & Sedang & $1.5915-2.3714$ \\
& Rendah & $2.3714-3.1513$ \\
& Sangat & $0.0592-0.7461$ \\
& Tinggi & \\
& Tinggi & $0.7461-1.4329$ \\
Seluruh & Sedang & $1.4329-2.1198$ \\
Fasilitas & Rendah & $2.1198-2.8066$ \\
Kesehatan & Sangat & $0.0434-0.9249$ \\
& Tinggi & \\
& Tinggi & $0.9249-1.8065$ \\
& Sedang & $1.8065-2.6880$ \\
\hline
\end{tabular}

Perhitungan nilai minimum dan maksimum menuju fasilitas kesehatan dari sentroid setiap kelurahan diperoleh nilai maksimum 3.2711 untuk kelompok rumah sakit. Nilai indeks maksimum 4.0686 untuk kelompok puskesmas. Untuk kelompok klinik diperoleh hasil perhitungan nilai maksimum 3.3518. Keseluruhan fasilitas kesehatan diperoleh hasil perhitungan nilai maksimum 3.7644.

Fasilitas kesehatan rumah sakit memiliki nilai indeks maksimum yang paling kecil daripada kelompok fasilitas kesehatan yang lain. Menurut Hadi et al. (2013) fasilitas kesehatan yang memiliki indeks maksimum terkecil merupakan fasilitas kesehatan dengan sebaran paling merata. sehingga rumah sakit merupakan 
fasilitas kesehatan dengan sebaran paling merata diantara fasilitas kesehatan yang lain.

Tabel 2. Kelas indeks aksesibilitas kelurahan menuju fasilitas kesehatan

\begin{tabular}{|c|c|c|}
\hline $\begin{array}{c}\text { Fasilitas } \\
\text { Kesehatan }\end{array}$ & $\begin{array}{c}\text { Kelas } \\
\text { Aksesibilitas }\end{array}$ & Rentang Indeks \\
\hline Rumah & Sangat & $0.1106-0.9007$ \\
\hline \multirow[t]{4}{*}{ Sakit } & Tinggi & \\
\hline & Tinggi & $0.9007-1.6908$ \\
\hline & Sedang & $1.6908-2.4810$ \\
\hline & Rendah & $2.4810-3.2711$ \\
\hline \multirow[t]{5}{*}{ Puskesmas } & Sangat & $0.0557-1.0589$ \\
\hline & Tinggi & \\
\hline & Tinggi & $1.0589-2.0621$ \\
\hline & Sedang & $2.0621-3.0653$ \\
\hline & Rendah & $3.0653-4.0686$ \\
\hline \multirow[t]{5}{*}{ Klinik } & Sangat & $0.0444-0.8712$ \\
\hline & Tinggi & \\
\hline & Tinggi & $0.8712-1.6981$ \\
\hline & Sedang & $1.6981-2.5249$ \\
\hline & Rendah & $2.5249-3.3518$ \\
\hline Seluruh & Sangat & $0.0824-1.0029$ \\
\hline Fasilitas & Tinggi & \\
\hline \multirow[t]{3}{*}{ Kesehatan } & Tinggi & $1.0029-1.9234$ \\
\hline & Sedang & $1.9234-2.8439$ \\
\hline & Rendah & $2.8439-3.7644$ \\
\hline
\end{tabular}

\section{Hasil klasifikasi wilayah grid}

Hasil klasifikasi wilayah grid dapat dilihat pada Gambar 2. Semakin gelap warna grid semakin rendah tingkat aksesnya, sebaliknya semakin terang warna grid semakin tinggi tingkat aksesnya. Klasifikasi indeks aksesibilitas dilakukan pada 155 wilayah grid menuju 16 rumah sakit. Dari hasil visualisasi pada Gambar 2 diperoleh luas wilayah serta persentase luas wilayah berdasarkan kelas indeks yang ada pada Tabel 3.
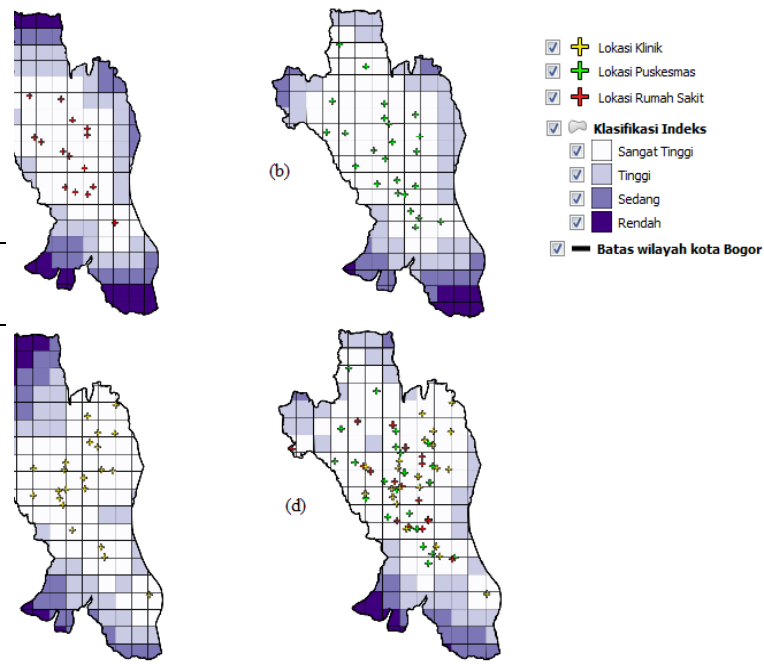

Gambar 2. Visualisasi hasil klasifikasi

(a) rumah sakit (b) puskesmas (c) klinik (d) seluruh fasilitas kesehatan terhadap wilayah grid.

Tabel 3. Luas wilayah grid berdasarkan kelas indeks menuju fasilitas kesehatan

\begin{tabular}{llrr}
\hline $\begin{array}{l}\text { Fasilitas } \\
\text { Kesehatan }\end{array}$ & $\begin{array}{l}\text { Kelas } \\
\text { Indeks }\end{array}$ & $\begin{array}{c}\text { Luas } \\
\text { Wilayah } \\
\left(\mathbf{k m}^{\mathbf{2}}\right)\end{array}$ & $\begin{array}{c}\text { Persentase } \\
(\boldsymbol{\%})\end{array}$ \\
\hline Rumah & Sangat & 56.23 & 47.29 \\
& Tinggi & & \\
& Tinggi & 35.82 & 30.12 \\
& Sedang & 16.18 & 13.61 \\
Puskesmas & Rendah & 10.68 & 8.98 \\
& Sangat & 70.70 & 59.45 \\
& Tinggi & & \\
& Tinggi & 31.74 & 26.69 \\
& Sedang & 11.57 & 9.73 \\
Klinik & Rendah & 4.90 & 4.12 \\
& Sangat & 64.57 & 54.30 \\
& Tinggi & & \\
& Tinggi & 27.72 & 23.31 \\
& Sedang & 18.73 & 15.75 \\
Seluruh & Rendah & 7.89 & 6.64 \\
Fasilitas & Sangat & 78.14 & 65.71 \\
Kesehatan & Tinggi & & \\
& Tinggi & 28.87 & 24.28 \\
& Sedang & 9.20 & 7.74 \\
& Rendah & 2.69 & 2.27 \\
\hline
\end{tabular}

Hasil klasifikasi indeks menunjukkan bahwa ada sekitar $10.68 \mathrm{~km}^{2}$ luas wilayah Kota Bogor yang memiliki akses rendah terhadap fasilitas kesehatan rumah sakit. Perhitungan indeks menuju 24 puskesmas diperoleh jarak terdekat menuju puskesmas yaitu, $0.05 \mathrm{~km}$ dan jarak terjauh yaitu $5.75 \mathrm{~km}$, serta jarak rata-rata yaitu $1.82 \mathrm{~km}$. Hasil klasifikasi indeks menunjukkan bahwa ada sekitar $4.90 \mathrm{~km}^{2}$ luas wilayah Kota Bogor yang memiliki tingkat 
akses Rendah menuju fasilitas kesehatan Puskesmas.

Klasifikasi indeks aksesibilitas menuju klinik diperoleh jarak terdekat menuju klinik $0.13 \mathrm{~km}$ dan jarak terjauh $6.24 \mathrm{~km}$ serta rata-rata jarak $2.22 \mathrm{~km}$. Hasil klasifikasi indeks menunjukkan sekitar $7.89 \mathrm{~km}^{2}$ luas wilayah Kota Bogor yang memiliki akses Rendah menuju klinik.

Klasifikasi 62 fasilitas kesehatan ini diperoleh jarak terdekat menuju suatu fasilitas kesehatan $0.05 \mathrm{~km}$, jarak terjauh $4.77 \mathrm{~km}$ serta jarak rata-rata $1.33 \mathrm{~km}$. Dari hasil klasifikasi, masih ada sekitar $2.27 \%$ atau $2.69 \mathrm{~km}^{2}$ wilayah Kota Bogor memiliki tingkat akses rendah menuju fasilitas kesehatan.

\section{Hasil klasifikasi wilayah kelurahan}

Klasifikasi indeks aksesibilitas menuju klinik dilakukan pada 22 klinik. Jarak terdekat menuju klinik sejauh $0.06 \mathrm{~km}$ dan jarak terjauh 5.26 serta rata-rata jarak $1.56 \mathrm{~km}$. Berdasarkan peta pada Gambar 3 diperoleh luas wilayah serta persentase luas wilayah setiap indeks aksesibilitas yang ada pada Tabel 4. Hasil klasifikasi indeks menunjukkan sekitar 12.10 $\mathrm{km}^{2}$ luas wilayah Kota Bogor yang memiliki akses Rendah menuju klinik.
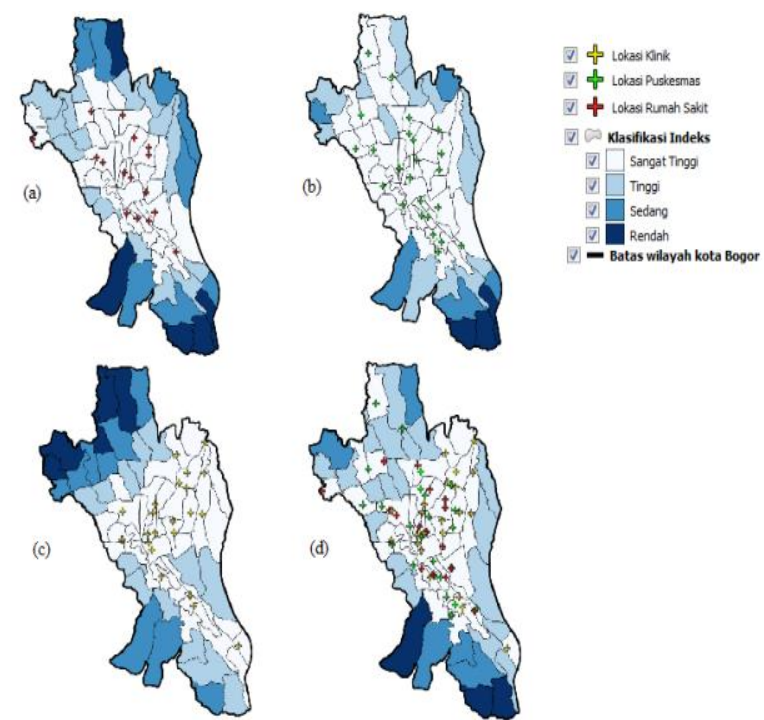

Gambar 3. Visualisasi hasil klasifikasi

(a) rumah sakit (b) puskesmas (c) klinik (d) seluruh fasilitas kesehatan terhadap wilayah kelurahan
Klasifikasi untuk 68 kelurahan menuju semua fasilitas kesehatan juga diperlukan untuk mengetahui hasil persebaran letak seluruh fasilitas kesehatan di Kota Bogor. Klasifikasi 62 fasilitas kesehatan ini diperoleh jarak terdekat menuju suatu fasilitas kesehatan $0.06 \mathrm{~km}$, jarak terjauh $3.14 \mathrm{~km}$ serta jarak rata-rata $0.83 \mathrm{~km}$. Berdasarkan peta diperoleh luas wilayah serta persentase luas wilayah setiap kelas indeks aksesibilitas yang ada pada Tabel 4. Ada sekitar $8 \%$ atau $10.06 \mathrm{~km}^{2}$ luas wilayah yang memiliki tingkat akses Rendah dalam mencapai fasilitas kesehatan di Kota Bogor.

Hasil visualisasi antara klasifikasi daerah grid dan kelurahan pada Gambar 2 dan Gambar 3 menunjukkan perbedaan hasil klasifikasi wilayah dalam setiap kelasnya. Pada wilayah kelurahan yang memiliki indeks tinggi akan dijustifikasi memiliki tingkat akses rendah menuju fasilitas kesehatan. Berbeda dengan wilayah grid, pada wilayah kelurahan tidak akan dijustifikasi memiliki akses rendah menuju fasilitas kesehatan, tetapi memperhatikan jarak dari grid yang telah terbentuk dalam satu kelurahan.

Tabel 4. Luas wilayah kelurahan berdasarkan kelas indeks menuju fasilitas kesehatan

\begin{tabular}{llcr}
\hline $\begin{array}{l}\text { Fasilitas } \\
\text { Kesehatan }\end{array}$ & $\begin{array}{c}\text { Kelas } \\
\text { Indeks }\end{array}$ & $\begin{array}{c}\text { Luas } \\
\text { Wilayah } \\
\left(\mathbf{k m}^{2}\right)\end{array}$ & $\begin{array}{c}\text { Persentase } \\
(\boldsymbol{\%})\end{array}$ \\
\hline Rumah & Sangat & 50.25 & 42.26 \\
Sakit & Tinggi & & \\
& Tinggi & 29.30 & 24.64 \\
& Sedang & 24.62 & 20.71 \\
& Rendah & 14.49 & 12.19 \\
Puskesmas & Sangat & 68.89 & 57.93 \\
& Tinggi & & \\
& Tinggi & 29.47 & 24.78 \\
& Sedang & 14.03 & 11.80 \\
& Rendah & 6.28 & 5.28 \\
Klinik & Sangat & 53.01 & 44.58 \\
& Tinggi & & \\
& Tinggi & 29.71 & 24.98 \\
& Sedang & 23.86 & 20.06 \\
Seluruh & Rendah & 12.10 & 10.17 \\
Fasilitas & Sangat & 54.16 & 45.55 \\
Kesehatan & Tinggi & & \\
& Tinggi & 37.84 & 31.82 \\
& Sedang & 16.61 & 13.97 \\
& Rendah & 10.06 & 8.46 \\
\hline
\end{tabular}


Hasil perhitungan luas wilayah yang dibahas pada Tabel 3 dan 4 juga menunjukkan perbedaan pada luas wilayah setiap kelasnya. Pada wilayah grid hanya memiliki 2,27\% luas wilayah yang tingkat aksesnya Rendah, sedangkan pada wilayah kelurahan lebih besar yaitu $8.46 \%$. Hasil perhitungan luas menunjukkan bahwa wilayah kelurahan diperoleh wilayah yang lebih luas dibandingkan dengan wilayah grid yang memiliki tingkat akses Rendah menuju suatu fasilitas kesehatan.

Hasil visualisasi pada Gambar 2 dan Gambar 3 menunjukan daerah yang selalu memiliki tingkat akses rendah dalam mencapai setiap fasilitas kesehatan. Untuk wilayah grid, tingkat akses rendah menuju fasilitas rumah sakit diperoleh 20 grid yang tersebar di Kelurahan Kencana, Mekarwangi, Kayumanis, Rancamaya, Pamoyanan, Mulyaharja, Harjasari, Kertamaya, dan Bojongkerta. Grid yang memiliki akses rendah terhadap puskesmas diperoleh sebanyak 9 grid yang tersebar di Kelurahan Rancamaya, Mulyaharja, Harjasari, Kertamaya, dan Bojongkerta. Grid yang memiliki tingkat akses rendah menuju klinik didapat 15 grid yang tersebar di Kelurahan Balungbang jaya, Kencana, Mekarwangi, Kayumanis, Pamoyanan, Mulyaharja, Curug, dan Situgede. Grid yang memiliki tingkat akses rendah terhadap seluruh fasilitas kesehatan ada 7 grid yang tersebar di Kelurahan Pamoyanan dan Mulyaharja. Sehingga diperoleh Grid yang selalu memiliki akses rendah terhadap seluruh kelompok fasilitas kesehatan yang ada di kelurahan Mulyaharja.

Pada wilayah kelurahan juga dapat dilihat daerah-daerah yang selalu memiliki tingkat akses Rendah. Kelurahan yang memiliki tingkat akses rendah terhadap fasilitas rumah sakit ada 5 kelurahan yaitu Kelurahan Kencana, Mulyaharja, Rancamaya, Harjasari, dan Bojongkerta. Kelurahan yang memiliki akses rendah terhadap puskesmas ada 3 Kelurahan yaitu Rancamaya, Harjasari, dan Bojongkerta. Tingkat akses rendah dalam mencapai klinik ada 5 kelurahan yaitu Kelurahan Balungbang jaya, Mekarwangi, Kayumanis, Curug, dan Situgede. Tingkat akses rendah menuju seluruh fasilitas kesehatan ada 3 kelurahan yaitu Kelurahan Mulyaharja, Rancamaya, dan Bojongkerta. Dari hasil yang diperoleh, grid yang selalu memiliki akses rendah terhadap seluruh kelompok fasilitas kesehatan tersebar di Kelurahan Mulyaharja. Kelurahan Rancamaya memiliki akses rendah untuk fasilitas kesehatan rumah sakit dan puskesmas. Kelurahan Bojongkerta memiliki akses rendah untuk fasilitas kesehatan rumah sakit dan puskesmas. Dari hasil tersebut diperoleh kelurahan yang selalu memiliki tingkat akses rendah yaitu kelurahan Rancamaya dan Bojongkerta. Hasil perolehan tingkat akses Rendah pada pendekatan grid dan kelurahan terdapat pada Kelurahan Mulyaharja.

\section{Pembuatan Modul Visualisasi}

Pembuatan modul visualisasi dilakukan menggunakan OpenGeo Suite yang mendukung dalam menampilkan peta berbasis web. Pembuatan web dasar menggunakan bahasa pemrograman Php Hypertext Preprocessor (PHP) serta untuk pembuatan layer-layer peta menggunakan GeoExplorer yang memanfaatkan GeoServer. GeoServer dapat terintegrasi dengan PostGIS yang dapat menyimpan data spasial dalam bentuk vektor maupun raster. Data peta yang disimpan dalam GeoServer dapat ditampilkan dengan menggunakan WMS OpenLayer atau GeoExplorer.

GeoExplorer dapat digunakan jika layer yang dibutuhkan telah dibuat. Oleh karena itu dibutuhkan GeoServer yang menyimpan data peta dalam bentuk data vektor. Data vektor peta diperoleh dari hasil digitasi yang dilakukan pada aplikasi QGIS. Data vektor yang dibutuhkan dapat diimpor langsung ke GeoServer. Data vektor yang digunakan adalah peta batas wilayah Kota Bogor, peta wilayah yang telah dipartisi per grid, peta wilayah yang telah dipartisi per kelurahan, peta jalan, peta fasilitas kesehatan, serta peta hasil klasifikasi indeks aksesibilitas rumah sakit, puskesmas, klinik dan seluruh fasilitas kesehatan.

Peta yang telah dimodifikasi menggunakan GeoExplorer dapat diintegrasikan dengan web dengan melakukan publish map. 
Pembuatan peta menghasilkan peta seperti Gambar 4. Navigasi peta yang digunakan adalah Print map, Get Feature Info, Measure, Zoom in/Zoom out, dan Show Legend. Print map dapat digunakan untuk mencetak peta, Get Feature Info yang berfungsi menampilkan atribut layer yang dipilih, Measure dapat digunakan untuk mengukur jarak dan luas dari daerah yang dipilih. Zoom in/Zoom out berfungsi untuk memperkecil dan memperbesar skala peta. Show Legend berfungsi menampilkan daftar layer yang ada pada tampilan peta.

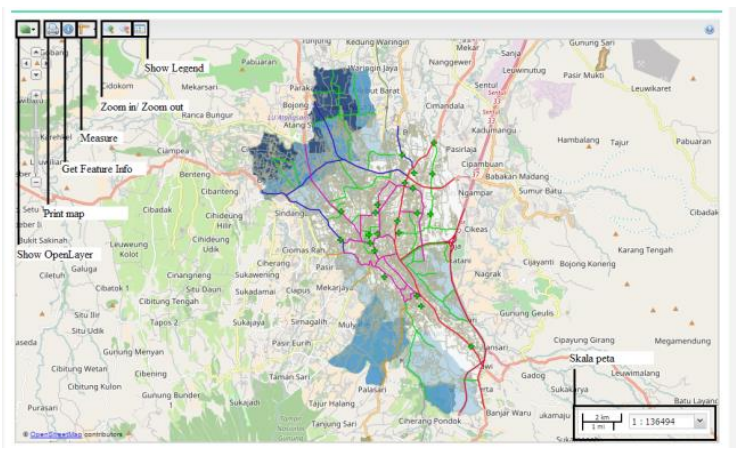

Gambar 4. Fitur navigasi peta

Pembuatan layout dibutuhkan untuk mempermudah dalam membuat tampilan. Terdapat beberapa bagian seperti Gambar 5, yaitu header, menu, judul, peta yang dilengkapi dengan navigasi dan skala. Menu Beranda berisi peta batas wilayah Kota Bogor serta ringkasan mengenai fasilitas kesehatan di Kota Bogor. Pada menu Klasifikasi terdapat 2 submenu, yaitu Grid dan Kelurahan. Submenu Grid berisi tampilan klasifikasi grid menuju setiap kelompok fasilitas kesehatan. Submenu Kelurahan berisi tampilan hasil klasifikasi kelurahan menuju fasilitas kesehatan. Menu Tentang Sistem berisi tabel keterangan fasilitas kesehatan yang ditampilkan pada peta. Pembuatan web menggunakan bahasa pemrograman PHP. Pembuatan submenu dari menu Klasifikasi dilakukan dengan merujuk link peta hasil klasifikasi setiap kelompok fasilitas yang diterbitkan oleh GeoExplorer sehingga hasil visualisasinya dapat dilihat pada Gambar 5.

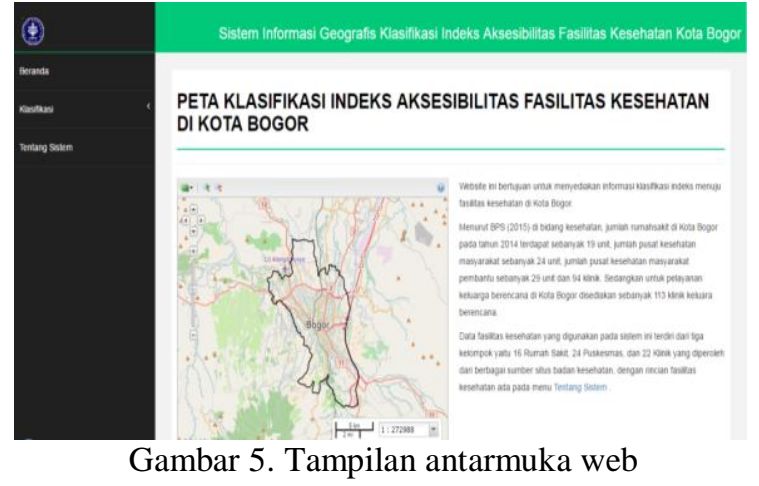

\section{KESIMPULAN DAN SARAN}

Kesimpulan yang diperoleh dari hasil penelitian ini adalah klasifikasi indeks aksesibilitas menuju setiap fasilitas kesehatan di Kota Bogor dapat ditentukan dan divisualisasikan dalam bentuk peta menggunakan perangkat lunak berbasis web. Perhitungan indeks aksesibilitas dapat dilakukan menggunakan metode ARIA yang sederhana dan tidak memerlukan banyak data. Hasil klasifikasi indeks aksesibilitas menuju fasilitas kesehatan di Kota Bogor menunjukkan bahwa jangkauan indeks rumah sakit memiliki nilai yang paling kecil dibandingkan dengan ketiga kelompok fasilitas kesehatan yang lain, sehingga dapat dikatakan pembangunan fasilitas kesehatan rumah sakit di Kota Bogor lebih tersebar merata dibandingkan dengan puskesmas dan klinik di Kota Bogor. Sebanyak 8.46\% wilayah kelurahan dan $2.27 \%$ wilayah grid di Kota Bogor memiliki tingkat akses rendah menuju seluruh fasiltas kesehatan. Dari hasil visualisasi terlihat bahwa Kelurahan Mulyaharja memiliki tingkat akses rendah terhadap seluruh fasilitas kesehatan di Kota Bogor. Terdapat beberapa hal yang dapat direkomendasikan untuk penelitian lanjutan. yaitu penambahan parameter dalam menghitung indeks aksesibilitas seperti waktu perjalanan (travel time) serta perlunya dilakukan kalibrasi jarak sebenarnya. 


\section{DAFTAR PUSTAKA}

Ahmad, S. (2012). A GIS Based Investigation of Spatial Accessibility to Health Care Facilities by Local Communities within an Urban Fringe Area of Melbourne. Thesis. Melbourne RMIT University.

Australian Institute of Health and Welfare (AIHW) Canberra. (2004). Rural, regional and remote health: A guide to remoteness classifications. Canberra: Australian Institute of Health and Welfare.

Badan Penyelenggara Jaminan Sosial (BPJS). (2016). Data Fasilitas Kesehatan. www.bpjskesehatan.go.id [Dec 16 ${ }^{\text {th }} 2016$ ].

Badan Pusat Statistik (BPS) Kota Bogor. (2016). Kota Bogor Dalam Angka. Bogor: BPS Kota Bogor.

The National Key Center for Social Applications of Geographical Information System (GISCA). (2001). Measuring Remoteness: Accessibility/ Remoteness Indeks of Australia (ARIA). Adelaide: Department of Health dan Aged Care Australia, University of Adelaide.

Hadi, P. L., Joewono, T. B., \& Santosa, W. (2013). Aksesibilitas Menuju Fasilitas Kesehatan di Kota Bandung. Jurnal Transportasi 13 (3): 213-222.

Haryanto, V. (2007). Analisis Penataan Fasilitas Kesehatan Kecamatan Kota Bogor Dalam Pembangunan Wilayah. Skripsi. Bogor: Institut Pertanian Bogor.

Kementerian Kesehatan Republik Indonesia. (2013). Sistem Informasi Geografis Info Fasilitas Kesehatan. gis.depkes.go.id [16 November 2016].

Sarup, J. \& Shukla, V. (2012). Web-Based Solution for Mapping Application using Open-Source Software Server. International Journal of Informatics and Communication Technology, 1 (2): 91:99. 